\title{
Response of polyamine pools in marine phytoplankton to nutrient limitation and variation in temperature and salinity
}

\author{
Qian Liu ${ }^{1}$, Naoyoshi Nishibori ${ }^{2}$, Ichiro Imai ${ }^{3}$, James T. Hollibaugh ${ }^{1, *}$ \\ ${ }^{1}$ Department of Marine Sciences, University of Georgia, Athens, Georgia 30602-3636, USA \\ ${ }^{2}$ Shikoku University Junior College, Shikoku University, Ojin, Tokushima 771-1192, Japan \\ ${ }^{3}$ Laboratory of Marine Biology, Graduate School of Fisheries Sciences, Hokkaido University, 3-1-1 Minatomachi, Hakodate, \\ Hokkaido 041-8611, Japan
}

\begin{abstract}
Previous field observations suggest that the composition of intracellular polyamine pools in phytoplankton determines the profile of polyamines released to the surrounding environment; thus, knowing how these pools vary among species and in response to factors affecting phytoplankton growth provides a basis for understanding fluctuations in dissolved polyamines. Our analyses of the polyamine content of axenic marine phytoplankton cultures show that intracellular polyamine pools are large (100s to $1000 \mathrm{~s} \mu \mathrm{mol}^{-1}$ of biovolume) and that putrescine and spermidine are the major compounds present; however, composition varied with species. Norspermidine and norspermine were the dominant compounds found in the diatom Thalassiosira pseudonana and the dinoflagellate Amphidinium carterae, respectively. We explored the effects of temperature, salinity and nutrient limitation on polyamine pools in T. pseudonana, and found that either increasing temperature or decreasing salinity increased polyamine concentrations in cells and in the growth medium. Nutrient (N, P or Si) limitation caused reductions of intracellular polyamine concentrations, but release was enhanced under $\mathrm{N}$ or Si limitation. Polyamine ratios in the media were not the same as in intracellular pools, suggesting selective release or uptake of polyamines by phytoplankton. Thus, the composition of the dissolved polyamine pool in seawater can vary significantly and on short time scales, depending on phytoplankton community composition and environmental factors affecting phytoplankton physiology. Our work provides experimental verification that biological mechanisms support inferences derived from environmental correlations about the factors controlling polyamine distributions in the sea.
\end{abstract}

KEY WORDS: Thalassiosira pseudonana $\cdot$ Chaetoceros $\cdot$ Amphidinium $\cdot$ Synechococcus $\cdot$ Dinoflagellate $\cdot$ Diatom $\cdot$ Cyanobacteria $\cdot$ Polyamine $\cdot$ Nutrient limitation

\section{INTRODUCTION}

Polyamines (PAs) are a group of related aliphatic compounds containing multiple primary or secondary amine functional groups. They are ubiquitous in both prokaryotic and eukaryotic cells. Putrescine (PUT), spermidine (SPD) and spermine (SPM) are 3 widely distributed and relatively abundant PAs that have been studied most thoroughly. The discovery of

\footnotetext{
*Corresponding author: aquadoc@uga.edu
}

less common PAs such as diaminopropane (DAP), norspermidine (NSPD) and norspermine (NSPM) in some organisms (Rodriguez-Garay et al. 1989, Hamana \& Matsuzaki 1992) has recently attracted attention due to their potential role in newly discovered biochemical pathways (Lee et al. 2009).

PAs are essential for cellular growth, regulating cell division and maintaining normal physiological function (Tabor \& Tabor 1985, Kusano et al. 2007).

() The authors 2016. Open Access under Creative Commons by Attribution Licence. Use, distribution and reproduction are unrestricted. Authors and original publication must be credited. 
They carry positive charges (2 in PUT; 4 in SPM) at physiological pH (7.4), and contribute to stabilizing membranes and nucleic acids by binding to negatively charged groups (Galston \& Sawhney 1990, Incharoensakdi et al. 2010, Orsini et al. 2011). A correlation between RNA synthesis and SPD concentration indicates that PAs could regulate RNA synthesis or indirectly affect protein synthesis (Stevens 1970). PA metabolism can change in higher plants in response to abiotic stresses; PUT concentration usually changes as a strategy for protecting cells against osmotic stress, salinity, hypoxia, etc. (Bouchereau et al. 1999, Alcázar et al. 2006, Incharoensakdi et al. 2010).

Eukaryotes normally synthesize PUT directly from L-ornithine by ornithine decarboxylase, or from arginine by a combination of arginine decarboxylase and agmatine ureohydrolase (Tabor \& Tabor 1985). PUT is the precursor of SPD, and subsequent metabolism produces SPM or thermospermine by the addition of aminopropyl groups from decarboxylated S-adenosyl methionine (Fuell et al. 2010). Oxidation of SPD or SPM to DAP by a spermine synthase orthologue can produce the tetraamine NSPM with an intermediate triamine NSPD (Bagga et al. 1991). The biosynthesis of PAs in eukaryotic phytoplankton is primarily controlled by ornithine decarboxylase activity (Theiss et al. 2002), while the arginine decarboxylase controlled pathway dominates in prokaryotic cyanobacteria (Incharoensakdi et al. 2010). Two enzymes related to PA synthesis (ornithine decarboxylase, EC 4.1.1.17 and spermidine synthase, EC 2.5.1.16) have been identified in the genome sequence of the diatom Thalassiosira pseudonana (Armbrust et al. 2004).

PA distributions in the ocean are usually correlated with phytoplankton biomass and bacterial production (Lee 1992, Lee \& Jørgensen 1995, Lu et al. 2014, Liu et al. 2015). PUT and SPD are ubiquitous and relatively abundant (low nmol $\mathrm{l}^{-1}$ ), with other PAs present either at lower levels (e.g. SPM, pmol $1^{-1}$ ) or only detected occasionally (e.g. NSPD, NSPM, diaminopropane and cadaverine; Nishibori et al. 2001a,b, 2003, Liu et al. 2015). Based on our previous work (Liu et al. 2015), we hypothesized that the PA composition of seawater is determined by the balance between release of PAs from phytoplankton and uptake by bacterioplankton. As the source of PAs, phytoplankton might play a more important role than bacterioplankton in determining PA profiles in the environment because species-specific differences in the composition of intracellular PA pools could affect the composition of PAs released into the environment.
Moreover, environmental factors such as temperature, salinity and nutrient status might affect the composition of intracellular PA pools and thus PA release from algal cells, resulting in spatial and temporal changes of PA profiles.

We studied the variability of PA profiles in representative phytoplankton to address this question. The species we selected represent groups that are commonly found in seawater and cover a spectrum of phylogeny and cell sizes (see Table 1). Diatoms have a wide geographic distribution and are often important in coastal algal blooms. The diatom T. pseudonana is commonly used for physiological studies and its genome has been sequenced (Armbrust et al. 2004). Thus, we chose to use T. pseudonana for a detailed study of intracellular PA pools and PA release in response to different environmental conditions. A PA uptake experiment was also performed to evaluate the ability of $T$. pseudonana to remove PAs from the medium and to determine if PA uptake was affected by environmental conditions or nutritional status.

\section{MATERIALS AND METHODS}

\section{Profiles of extractable PAs}

The diatoms Thalassiosira pseudonana (CCMP 1335) and Chaetoceros sp. (CCMP199), the cyanobacterium Synechococcus sp. (CCMP1334) and the dinoflagellate Amphidinium carterae Hulburt (CCMP 1314) were purchased from the National Center for Marine Algae and Microbiota (NCMA). These axenic, pure cultures were inoculated into $100 \mathrm{ml}$ of culture media (f/2 for diatoms and f/2-Si for the cyanobacterium and the dinoflagellate; salinity = 35 ) in $300 \mathrm{ml}$ glass Erlenmeyer flasks, and were grown at $18^{\circ} \mathrm{C}$ under a cool-white fluorescent light intensity of $100 \mu \mathrm{mol}$ photons $\mathrm{m}^{-2} \mathrm{~s}^{-1}$ in a $14 \mathrm{~h}$ light:10 h dark cycle. After a period of adaptation to the laboratory environment ( 2 or 3 transfers), a portion of the stock culture of each species was transferred into $100 \mathrm{ml}$ of fresh medium at an initial density of $10^{4}$ cells $\mathrm{ml}^{-1}$ for diatoms and A. carterae and $10^{5}$ cells $\mathrm{ml}^{-1}$ for Synechococcus sp. All experiments were conducted using batch cultures in triplicates. Culture sterility was checked frequently with an epi-illuminated fluorescence microscope (DM-RXA, Leica) after staining with 4', 6-diamidino2-phenylindole (DAPI; Porter \& Feig 1980). Growth rates and changes in cell volumes of the diatoms and the dinoflagellate were determined by counting 
them daily using a Z2 Coulter ${ }^{\circledR}$ Particle Count and Size Analyzer (Beckman), while Synechococcus sp. was measured and quantified by epi-illuminated fluorescence microscopy with DAPI stain. Samples of diatom and Synechococcus sp. cultures $\left(\sim 5 \times 10^{7}\right.$ cells) was collected at the end of exponential growth and harvested by centrifugation at $3000 \times g$ for $10 \mathrm{~min}$. The cell pellet was washed with sterile artificial seawater, centrifuged again, then dispersed into $2 \mathrm{ml}$ of ice-cold $6 \%$ perchloric acid (PCA) (Lu \& Hwang 2002). A total of $60 \mathrm{ml}$ of the A. carterae culture was collected and adjusted to $\mathrm{pH}$ 8.4. The cells were precipitated by addition of $\mathrm{KAl}\left(\mathrm{SO}_{4}\right)_{2}(0.3 \mathrm{~mol}$ $\mathrm{l}^{-1}$ ) to a final concentration of $1 \mathrm{mmol} \mathrm{l}^{-1}$, then centrifuged at $1500 \times g$ for $10 \mathrm{~min}$ (Haxo et al. 1976). The pellet was dispersed in $2 \mathrm{ml} 6 \%$ PCA, sonicated for $30 \mathrm{~min}$ and centrifuged at $10000 \times g$ for $10 \mathrm{~min}$. The supernatant was collected and stored at $-80^{\circ} \mathrm{C}$ until analysis. We considered PAs in the supernatant to be free PAs extracted from the cells, versus combined PAs that are covalently bonded in macromolecules such as silafins. However, it is likely that under physiological conditions a large fraction of the extractable PAs are not dissolved in the cytosol, but rather are bonded ionically to negatively charged groups in the cell, such as the phosphate backbone of nucleic acids. The concentration of PAs in the intracellular pools of phytoplankton is expressed as $\mu \mathrm{mol} \mathrm{l}^{-1}$ of biovolume and was calculated by dividing the amount of PAs extracted from a sample by the total biovolume of cells in that sample (calculated from abundance and measurements of cell dimensions or of equivalent spherical diameter as determined by the Coulter Counter).

\section{Extractable and extracellular PA contents during growth of $T$. pseudonana}

A total of $300 \mathrm{ml}$ of $\mathrm{f} / 2$ media in $500 \mathrm{ml}$ Erlenmeyer flasks was inoculated with $T$. pseudonana to an initial density of $10^{4}$ cells $\mathrm{ml}^{-1}$. The experiment was conducted in triplicate batch cultures under the same culture conditions as above. Samples $(20 \mathrm{ml})$ were withdrawn each day and processed as above until the growth rate declined. A total of $9 \mathrm{ml}$ of culture medium (supernatant from the first centrifugation) was placed into a $15 \mathrm{ml}$ Teflon tube, then $1 \mathrm{ml} 60 \%$ PCA was added to attain a final concentration of $6 \%$ PCA. The samples were frozen at $-80^{\circ} \mathrm{C}$ for later measurement of PA concentrations in the culture medium. The concentration of extractable PA is expressed as amol cell ${ }^{-1}$, calculated from the amount of
PAs extracted from the cell pellet divided by the number of cells in the pellet.

\section{Extractable and extracellular PA contents of T. pseudonana at different temperatures and salinities}

Triplicate $100 \mathrm{ml}$ cultures initially containing $10^{4}$ T. pseudonana cells $\mathrm{ml}^{-1}$ were incubated at 18 and $24^{\circ} \mathrm{C}$. Cells were harvested as above from duplicate $20 \mathrm{ml}$ samples of each culture at the end of the exponential growth phase. Salinity manipulation experiments used cultures grown in modified artificial seawater media (ESAW: $\left[\mathrm{NO}_{3}\right]=549 \mu \mathrm{mol} \mathrm{l}^{-1}$; $\left[\mathrm{PO}_{4}\right]=25.6 \mu \mathrm{mol} \mathrm{l} \mathrm{l}^{-1}$; and $\left[\mathrm{SiO}_{3}\right]=106 \mu \mathrm{mol} \mathrm{l} \mathrm{l}^{-1}$, described on the Canadian Center for the Culture of Micro-organisms website, http://www3.botany.ubc. ca/cccm/NEPCC/esaw.html; Harrison et al. 1980) prepared at salinities of 15, 25, 35 and 45 by adding the corresponding additional amounts of the salts ( $\mathrm{NaCl}, \mathrm{MgCl}_{2} 6 \mathrm{H}_{2} \mathrm{O}$ and $\mathrm{Na}_{2} \mathrm{SO}_{4}$ ) used in this medium. The $\mathrm{pH}$ was adjusted to 8.2. T. pseudonana cells were grown and transferred 3 times $(\sim 12 \mathrm{~d}$ in total) under the experimental conditions (temperature and salinity) tested before the experiment began. Cell pellets and supernatants were collected at the end of the exponential growth phase and processed as above.

\section{Extractable and extracellular PA contents of T. pseudonana grown under N, P or Si limitation}

Nutrient limitation was attained by decreasing the relative concentration of the target nutrient in the medium while keeping the concentrations of the other nutrients the same as that of the original ESAW formulation. A semi-continuous culture approach was applied, in which half of the culture was replaced daily by new medium once growth of the initial culture had reached the end of the exponential phase (Kilham 1978). Nitrogen-limited cultures were grown in ESAW prepared with 0, 10, 20 and $50 \mu \mathrm{mol}$ $l^{-1} \mathrm{NaNO}_{3}$ and inoculated with $\mathrm{N}$-starved T. pseudonana cells at an initial density of $10^{4}$ cells $\mathrm{ml}^{-1}$. Cell pellets and supernatant were collected and processed as above after 5 doubling cycles. Similar experiments were conducted for P- and Si-limited cultures using ESAW prepared with different phosphate $\left(0,0.5,1\right.$ and $\left.2 \mu \mathrm{mol} \mathrm{l}^{-1}\right)$ and silicate $(0,5,20$ and $50 \mu \mathrm{mol} \mathrm{l}^{-1}$ ) concentrations, respectively. The Silimited cultures were grown in $250 \mathrm{ml}$ Nalgene polycarbonate bottles (Thermo Scientific). 


\section{PA measurement}

The acidified samples were injected into a highperformance liquid chromatography (HPLC) system equipped with a $2.6 \mathrm{~mm}$ i.d. $\times 50 \mathrm{~mm}$ cation exchange column (Hitachi No. 2619F, $5 \mu \mathrm{m}$ particle size) maintained at $75^{\circ} \mathrm{C}$. PAs were eluted using 2 buffers. Buffer A consisted of $0.045 \mathrm{~mol} \mathrm{l}^{-1}$ sodium citrate, $0.061 \mathrm{~mol} \mathrm{l}^{-1}$ citric acid, and $0.064 \mathrm{~mol} \mathrm{l}^{-1}$ $\mathrm{NaCl}(\mathrm{pH}=4)$; Buffer B contained $0.2 \mathrm{~mol} \mathrm{l}^{-1}$ sodium citrate, $2.0 \mathrm{~mol} \mathrm{l}^{-1} \mathrm{NaCl}(\mathrm{pH}=7)$. The gradient program was as follows: start at $50 \%$ B for 6 min and change to $85 \%$ for $6 \mathrm{~min}$, change to $90 \%$ B for $3 \mathrm{~min}$ and then change to $100 \%$ B for 50 min; with a flow rate $0.25 \mathrm{ml} \mathrm{min}^{-1}$. After reaction with $o$-phthaldialdehyde (OPA) reagent $(0.8 \mathrm{~g}$ OPA in $10 \mathrm{ml}$ ethanol, $15.0 \mathrm{~g}$ boric acid, $8.0 \mathrm{~g}$ sodium hydroxide, $2.0 \mathrm{ml}$ of 2-mercaptoethanol in $1 \mathrm{l}$ of OPA reagent), PAs were detected on a fluorescence spectrometer at excitation and emission wavelengths of 340 and $435 \mathrm{~nm}$.

\section{PA uptake by $T$. pseudonana}

ESAW was prepared with salinities of 22 and 32, as above. These media were amended with sodium nitrate to final concentrations of 20 or $50 \mu \mathrm{mol} \mathrm{l}^{-1}$. T. pseudonana cells were grown under these conditions as semi-continuous cultures for 5 generations, then $20 \mathrm{ml}$ of culture was inoculated into $20 \mathrm{ml}$ of fresh medium of the same composition. Radiolabeled PUT $\left(\left[2,3-{ }^{14} \mathrm{C}\right]\right.$-putrescine, $100 \mathrm{mCi} \mathrm{mmol}^{-1}$ and $\left[1,4-{ }^{14} \mathrm{C}\right]-$ putrescine, $110 \mathrm{mCi} \mathrm{mmol}^{-1}$; American Radiolabeled Chemicals) were mixed in equimolar proportions and added to $40 \mathrm{ml}$ of culture to a final concentration of $50 \mathrm{nmol} \mathrm{l}^{-1}\left(\sim 0.2 \mu \mathrm{Ci}\right.$ tube $\left.{ }^{-1}\right)$. Cultures were incubated for $24 \mathrm{~h}$ under a $14 \mathrm{~h}$ light:10 h dark cycle. Either 6 or $8 \mathrm{ml}$ of culture was collected at 1, 6, 12, 19 and $24 \mathrm{~h}$, and filtered through $0.45 \mu \mathrm{m}$ pore size Millipore filters (type HA) held on a model 1225 Sampling Manifold (Millipore). Each filter was rinsed to remove unincorporated substrate, and then placed in a $7 \mathrm{ml}$ scintillation vial. Scintillation cocktail was added prior to counting on a Tri-carb ${ }^{\circledR}$ 2910TR Liquid Scintillation Analyzer (PerkinElmer).

\section{Statistical analysis}

Student's $t$-test and an analysis of variance (ANOVA) were used to test statistical significance of differences between treatments. Data were logarithmtransformed where necessary to achieve normality. Correlations between 2 variables were analyzed as Pearson product-moment correlations and the correlation coefficient (r) was calculated. Statistical significance was evaluated at a $95 \%$ confidence interval.

\section{RESULTS}

\section{PA profiles in phytoplankton}

The species we tested, which represented 3 widely different taxonomic groups, contained significant but distinct, extractable PA profiles at the late exponential phase. Total extractable PA concentrations ranged from 168 to $1176 \mu \mathrm{mol} \mathrm{l^{-1 }}$ (Table 1). Thalassiosira pseudonana (CCMP1335) had the most diverse PA pool, which was dominated by NSPD and PUT, followed by SPD, DAP and NSPM. The other diatom (Chaetoceros sp., CCMP199) only contained PUT and SPD, at concentrations similar to those in T. pseudonana (Table 1). The concentration of extractable PAs in the cyanobacterium Synechococcus sp. (CCMP1334) was similar to that in the diatoms; however, SPD was the major PA, followed by PUT

Table 1. Extractable polyamine (PA) concentrations in 4 phytoplankton species. DAP: diaminopropane; PUT: putrescine; SPD: spermidine; NSPD: norspermidine; NSPM: norspermine. Extractable PA concentration values are given as means \pm SE

\begin{tabular}{|c|c|c|c|c|c|c|c|c|}
\hline \multirow[t]{2}{*}{ Phytoplankton species } & \multirow[t]{2}{*}{ Class } & \multirow{2}{*}{$\begin{array}{l}\text { Cell volume } \\
\qquad\left(\mu \mathrm{m}^{3}\right)\end{array}$} & \multicolumn{6}{|c|}{ - Extractable PA concentration $\left(\mu \mathrm{mol} \mathrm{l}^{-1}\right)$} \\
\hline & & & DAP & PUT & SPD & NSPD & NSPM & Total \\
\hline $\begin{array}{l}\text { Thalassiosira pseudonana } \\
\text { (CCMP1335) }\end{array}$ & Bacillariophyceae & 50 & $36 \pm 1$ & $141 \pm 16$ & $40 \pm 5$ & $188 \pm 11$ & $32 \pm 5$ & $437 \pm 26$ \\
\hline $\begin{array}{l}\text { Chaetoceros sp. } \\
\text { (CCMP199) }\end{array}$ & Bacillariophyceae & 48 & - & $133 \pm 11$ & $41 \pm 3$ & - & - & $174 \pm 14$ \\
\hline $\begin{array}{l}\text { Synechococcus sp. } \\
\text { (CCMP1334) }\end{array}$ & Cyanophyceae & 0.5 & & $40 \pm 22$ & $120 \pm 20$ & $8 \pm 6$ & - & $168 \pm 40$ \\
\hline $\begin{array}{l}\text { Amphidinium carterae } \\
\text { Hulburt (CCMP1314) }\end{array}$ & Dinophyceae & 427 & - & - & - & - & $1176 \pm 95$ & $1176 \pm 95$ \\
\hline
\end{tabular}


and NSPD. The dinoflagellate Amphidinium carterae (CCMP1314) contained the largest PA pool of the species we studied; NSPM was the only PA detected in the cell (Table 1). SPM was not detected in the cells of any of these phytoplankton cultures.

\section{Composition and concentration of extractable and extracellular PA during the growth of T. pseudonana}

Extractable PA concentrations and the PA profile changed as T. pseudonana cultures grew (Fig. 1a,b). Extractable PAs increased monotonically from $2.1 \pm$ $0.4 \mathrm{amol} \mathrm{cell}^{-1}$ during the lag phase to $31 \pm 3 \mathrm{amol}$ cell $^{-1}$ during the late stationary phase. The greatest increase $\left(8 \pm 3\right.$ amol cell $\left.^{-1} \mathrm{~d}^{-1}\right)$ occurred during the late stationary phase (Fig. 1a). NSPD was the predominant PA present in the extractable PA pool at all stages of cell growth, accounting for $100 \%$ of the extractable pool during the lag phase and $54 \%$ at the late stationary phase. PUT, SPD and NSPM were detected during exponential growth in similar concentrations $\left(<2 \mathrm{amol} \mathrm{cell}^{-1}\right)$. However, the PUT concentration increased to $8.7 \pm 2.1 \mathrm{amol} \mathrm{cell}^{-1}$ during the late stationary phase, when concentrations of SPD and NSPM were $2.6 \pm 0.6$ and $2.9 \pm 0.7 \mathrm{amol}$ cell $^{-1}$, respectively (Fig. 1b). NSPD was the only PA detected in the medium of $T$. pseudonana cultures (Fig. 1c), in contrast to the more complex profile of the extractable PA pool. The concentration of NSPD in the medium did not change significantly during growth (1-way ANOVA, $\mathrm{p}=0.7$ ), being $2.3 \mathrm{nmol} \mathrm{l}^{-1}$ on average (Fig. 1c).

\section{Effects of temperature and salinity on PA profiles of T. pseudonana}

Temperature had a significant effect on extractable PA pools of $T$. pseudonana cultures (Fig. 2a) (at $18^{\circ} \mathrm{C}$ : $20 \pm 1 \mathrm{amol} \mathrm{cell}^{-1}$; at $24^{\circ} \mathrm{C}: 45 \pm 7 \mathrm{amol} \mathrm{cell}{ }^{-1}$; $t$-test, $\mathrm{p}<0.002$ ). Concentrations of all individual PAs increased significantly with temperature $(t$-test, $\mathrm{p}<$ 0.005 ) except NSPM ( $t$ test, $\mathrm{p}=0.3$ ). Differences in the relative increase of individual PA concentrations resulted in changes in PA profiles. PUT increased most dramatically, from $4.2 \pm 0.3 \mathrm{amol} \mathrm{cell}^{-1}$ at $18^{\circ} \mathrm{C}$ to $19.1 \pm 2.5 \mathrm{amol} \mathrm{cell}^{-1}$ at $24^{\circ} \mathrm{C}$, and became the dominant PA in cells grown at $24^{\circ} \mathrm{C}$ (Fig. 2a). The concentration and composition of extracellular PAs were also different under the 2 temperature treatments (Fig. 2b). Significantly higher concentrations
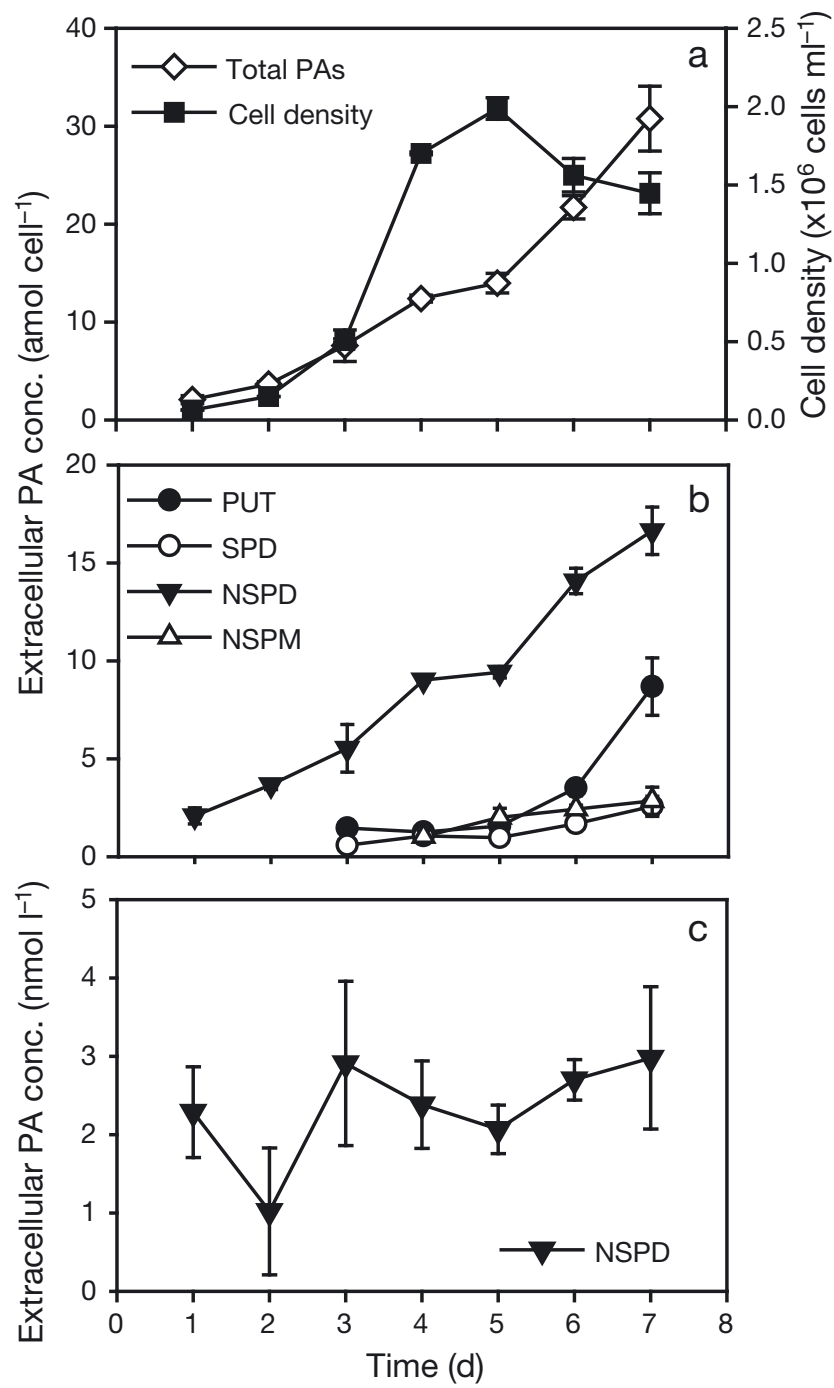

Fig. 1. Changes in (a) cell densities and extractable polyamine (PA) pools of Thalassiosira pseudonana, (b) concentrations of individual extractable PAs (PUT: putrescine; SPD: spermidine; NSPD: norspermidine; NSPM: norspermine), and (c) PA concentrations in the medium at different growth stages. Concentrations of PUT, SPD and NSPM below the detection limit are not shown. Error bars: standard error of 6 replicates (duplicate analyses from triplicate cultures). Lag phase: Days 1 and 2; exponential phase: Days 3 and 4 ; stationary phase: Day 5; late stationary phase: Days 6 and 7

of PA were found in the medium at $24^{\circ} \mathrm{C}(5.7 \pm$ $\left.1.8 \mathrm{nmol} \mathrm{l}^{-1}\right)$ than at $18^{\circ} \mathrm{C}\left(2.2 \pm 0.5 \mathrm{nmol} \mathrm{l}^{-1}\right)$. NSPD was detected in the medium under both growth temperatures, but NSPM was only detected at $24^{\circ} \mathrm{C}$ (Fig. 2b). We found a significant correlation between extracellular and extractable PA concentrations $(\mathrm{r}=$ $0.7, \mathrm{p}=0.01$; Fig. $2 \mathrm{c}$ ).

The salinity ( $\mathrm{S}$ ) of the culture medium also influenced the extractable PA content of T. pseudonana (at $\mathrm{S}=15: 36 \pm 5 \mathrm{amol} \mathrm{cell}^{-1} ; \mathrm{S}=25: 18 \pm 1 \mathrm{amol} \mathrm{cell}^{-1}$, 


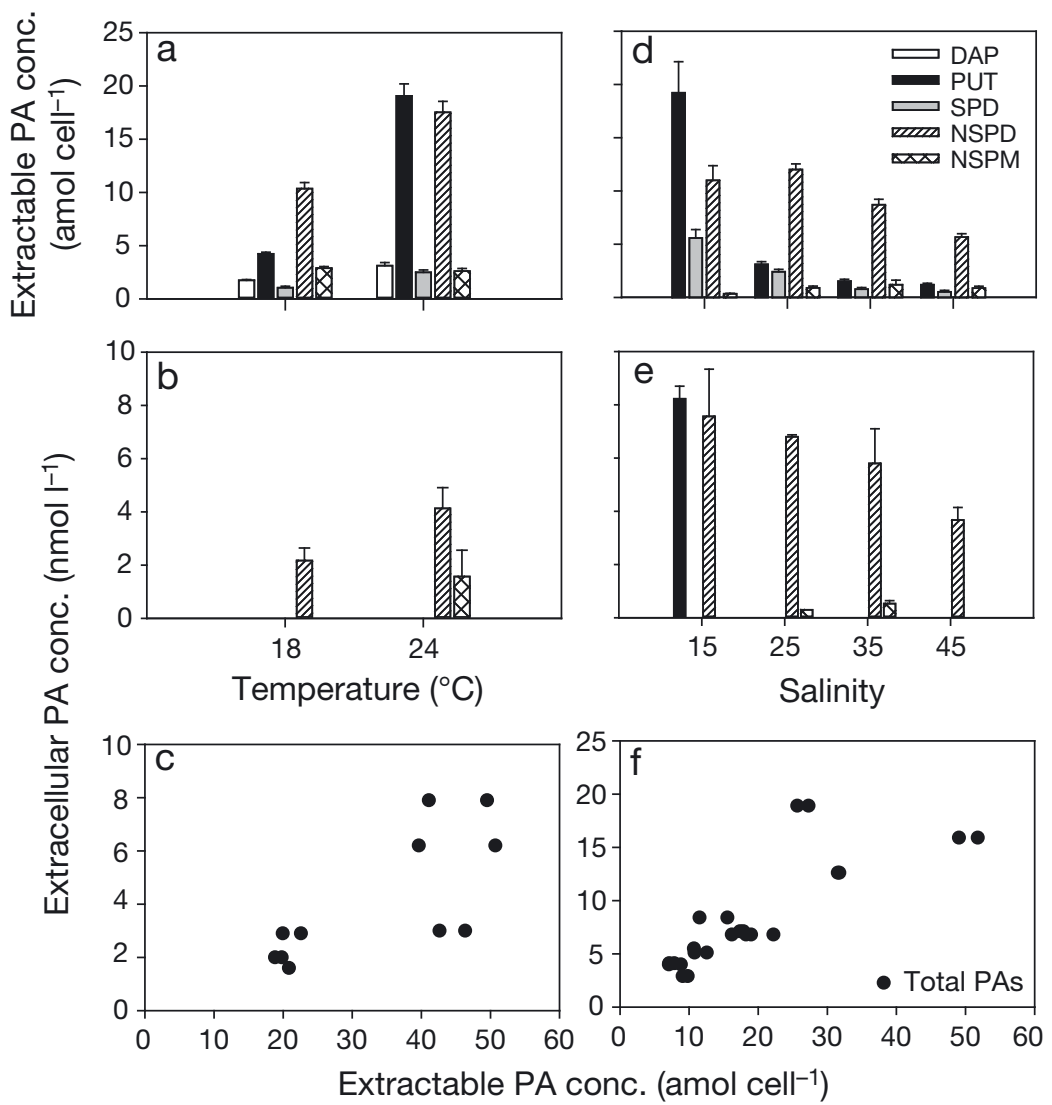

Fig. 2. Concentrations of (a) extractable polyamines (PAs) (DAP: diaminopropane; PUT: putrescine; SPD: spermidine; NSPD: norspermidine; NSPM: norspermine), (b) extracellular PAs during the growth of Thalassiosira pseudonana at 18 and $24^{\circ} \mathrm{C}$. Panels (d) and (e) show the same variables as (a) and (b), respectively, but under conditions of different salinity $(15,25,35$ and 45$)$. Concentrations of PAs below the detection limit are not shown. Error bars: standard error of 6 replicates (duplicate analyses from triplicate cultures). Concentrations of extracellular and extractable PAs are positively correlated with (c) temperature $(\mathrm{r}=0.7, \mathrm{p}=0.01)$ or (f) salinity $(\mathrm{r}=0.8, \mathrm{p}<0.001)$ lular PA concentrations also changed with salinity (1-way ANOVA, p < 0.001 ; Fig. 2e) and were correlated with extractable PA pools $(\mathrm{r}=0.8, \mathrm{p}<$ 0.001; Fig. 2f). NSPD was found in the medium at all salinities, and its concentration did not change significantly ( $6 \mathrm{nmol} \mathrm{l}^{-1}$; 1-way ANOVA, p > 0.05). NSPM was only detected at salinities of 25 and 35, at very low concentrations $\left(<0.6 \mathrm{nmol}^{-1}\right)$. PUT was present in the medium at $\mathrm{S}=15(8.2 \pm 0.5 \mathrm{nmol}$ $\mathrm{l}^{-1}$; Fig. 2e), coincident with the increase in extractable PUT concentration shown in Fig. 2d.

\section{Effect of nutrient availability on PA profiles of $T$. pseudonana}

The availability of $\mathrm{N}, \mathrm{P}$ or $\mathrm{Si}$ in the culture medium affected the concentration of extractable PA in T. pseudonana (Fig. 4). Final cell density increased with increasing initial nutrient concentration (Fig. 4), indicating that the nutrient tested (N, P or Si) was limiting growth in the treatment. Extractable PA pools of T. pseudonana increased as initial nitrate concentrations increased $(\mathrm{r}=0.96, \mathrm{p}=0.03$; Fig. 4a). PA pools in cells from cultures with no added nitrate were $\sim 1$ amol cell $^{-1}$, and contained only NSPD and NSPM. PUT and SPD were detected in
$\mathrm{S}=35: 12 \pm 1 \mathrm{amol} \mathrm{cell}{ }^{-1}$ and $\mathrm{S}=45: 8 \pm 1 \mathrm{amol} \mathrm{cell}^{-1}$; 1-way ANOVA, p < 0.05; Fig. 2d), and there was an inverse correlation between the size of the extractable PA pool (log-transformed) and salinity ( $r=0.95, p<0.001$; Fig. 3). As salinity decreased, all extractable PA pools increased except NSPM, which was low and variable at all salinities (range 0.3 to $\left.2.7 \mathrm{amol} \mathrm{cell}^{-1}\right)$. The NSPD pool increased significantly from $\mathrm{S}=45\left(5.7 \pm 0.7 \mathrm{amol} \mathrm{cell}{ }^{-1}\right)$ to $\mathrm{S}=25(12 \pm$ 1 amol cell ${ }^{-1}$ ) (1-way ANOVA, p < 0.05), then remained constant as salinity decreased to 15 . We found that mesohaline conditions $(\mathrm{S}=15)$ resulted in accumulation of PUT and SPD, with pools of $19.2 \pm$ 6.5 and $5.6 \pm 1.8$ amol cell $^{-1}$, respectively - significantly larger than those measured at higher salinities (1-way ANOVA and Tukey's HSD test, p < 0.05). PUT became the dominant PA at $\mathrm{S}=15$ (Fig. 2d). Extracel-

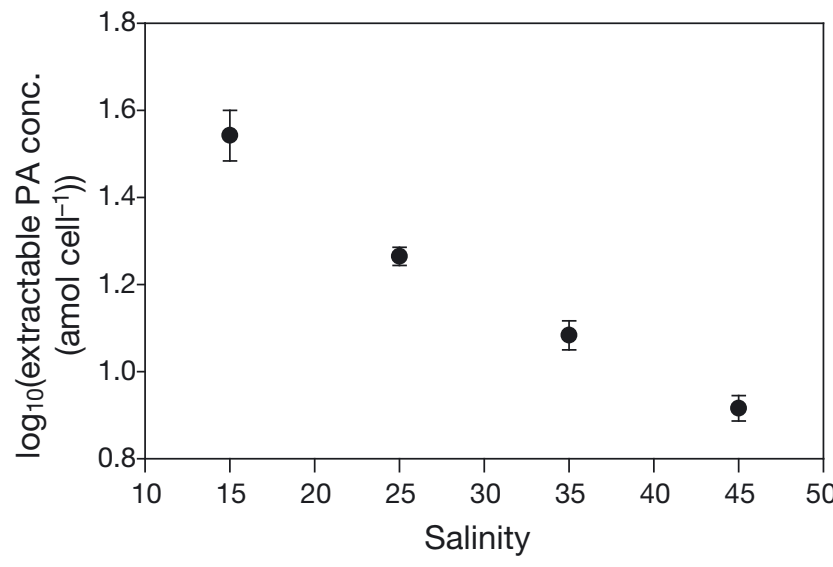

Fig. 3. Correlation between log-transformed extractable polyamine (PA) concentrations and salinity $(\mathrm{r}=0.95, \mathrm{p}<$ 0.001). Error bars: standard error of 6 replicates (duplicate analyses from triplicate cultures) 

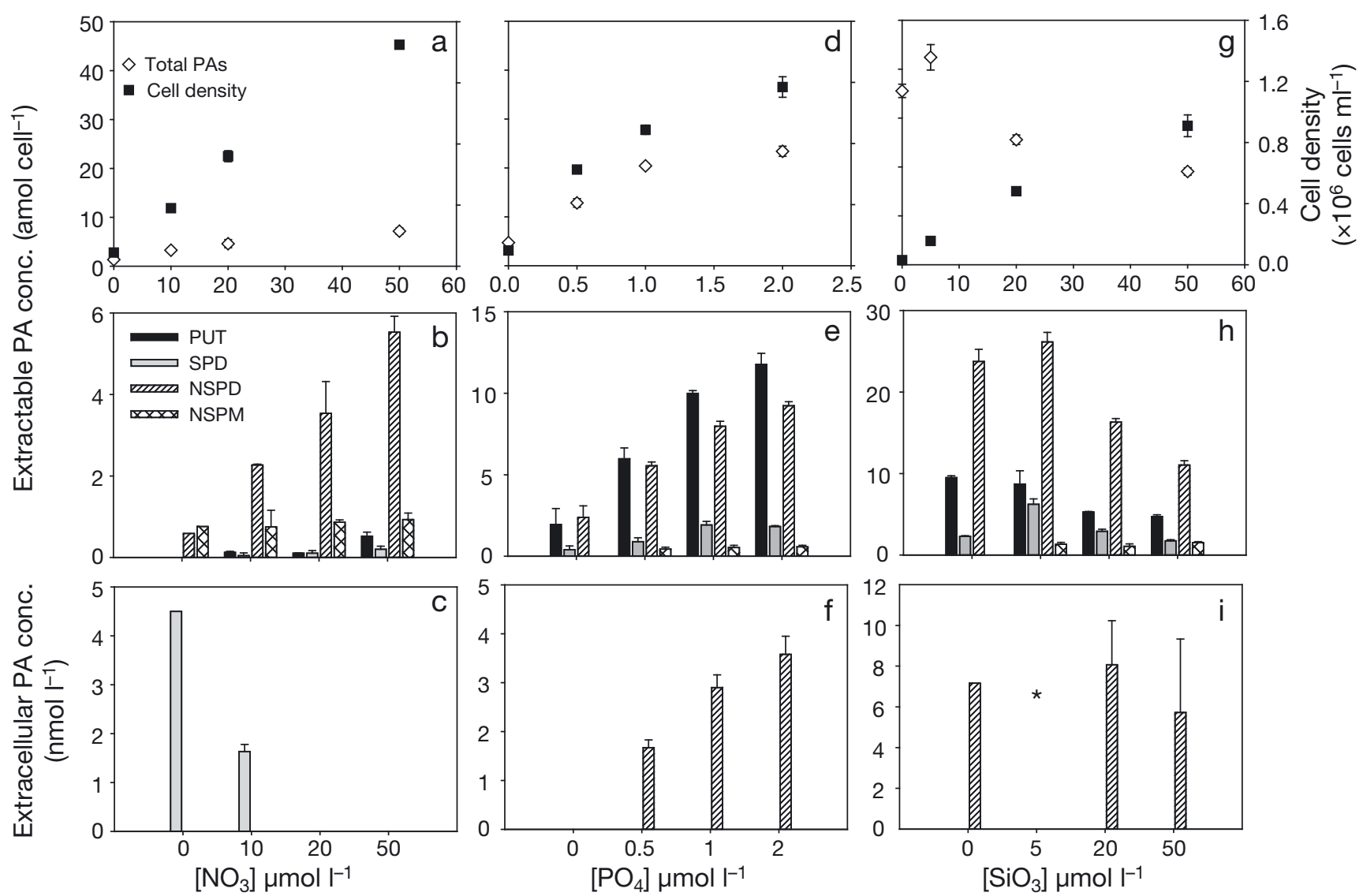

Fig. 4. (a) Cell densities and extractable polyamine (PA) concentrations, (b) individual extractable PA concentrations and (c) extracellular PA concentrations during the growth of Thalassiosira pseudonana under different initial nitrate concentrations $\left(0,10,20\right.$ and $\left.50 \mu \mathrm{mol} \mathrm{l^{-1 }}\right)$. Panels $(\mathrm{d}-\mathrm{f})$ and $(\mathrm{g}-\mathrm{i})$ show the same variables as $(\mathrm{a}-\mathrm{c})$, but for growth under different concentrations of phosphate $\left(0,0.5,1\right.$ and $\left.2 \mu \mathrm{mol}^{-1}\right)$ or silicate $\left(0,5,20\right.$ and $\left.50 \mu \mathrm{mol} \mathrm{l}^{-1}\right)$, respectively. Concentrations of PAs below the detection limit were not shown. Asterisk in (i) indicate no data available due to lost samples. Error bars: standard error of 6 replicates (duplicate analyses from triplicate cultures). PUT: putrescine; SPD: spermidine; NSPD: norspermidine; NSPM: norspermine

nitrate-amended cultures, but their pools were consistently low ( $\leq 0.5$ amol cell $^{-1}$; 1 -way ANOVA, p > 0.05 ; Fig. 4 b). NSPD varied similarly to total PA in that its extractable concentrations correlated with initial nitrate concentrations $(\mathrm{r}=0.97, \mathrm{p}=0.03)$, while the extractable pool of NSPM did not change in response to differences in $\mathrm{N}$ supplied (1-way ANOVA, $p>0.05$; Fig. 4b). PAs could only be detected in the medium of cultures with low nitrate amendments ( 0 and $10 \mu \mathrm{mol} \mathrm{l^{-1 }}$ ), and the extracellular PA concentration was significantly greater in these $\mathrm{N}$-starved cultures $\left(4.5 \mathrm{nmol} \mathrm{l}^{-1}\right)$ than in cultures receiving greater $\mathrm{N}$ amendments $\left(1.6 \mathrm{nmol} \mathrm{l}^{-1}\right.$; Fig. 4c). SPD was the only PA detected (Fig. 4c).

The extractable PA pool of P-limited cultures also increased with increasing initial $P$ concentrations $(\mathrm{r}=$ $0.9, \mathrm{p}<0.001$; Fig. 4d). PUT and NSPD were the major PAs detected, and their pool size correlated significantly with initial $\mathrm{P}$ additions $(\mathrm{r}=0.9, \mathrm{p}<$ 0.001). SPD pools increased as the initial $\left[\mathrm{PO}_{4}\right]$ increased from 0 to $1 \mathrm{\mu mol}^{-1}$, and then remained constant $\left(\sim 2 \mathrm{amol} \mathrm{cell}^{-1}\right)$. NSPM was only detected in Pamended cultures, and the pool size was similar under all treatments $\left(\sim 0.5 \mathrm{amol} \mathrm{cell}{ }^{-1}\right.$; 1 -way ANOVA, p > 0.05; Fig. 4e). Extracellular PAs were detected in P-amended culture medium, and NSPD was the only PA found. Concentrations of extracellular PA ranged from 1.7 to $3.6 \mathrm{nmol} \mathrm{l}^{-1}$ and correlated positively with initial $\mathrm{P}$ concentrations $(\mathrm{r}=0.9, \mathrm{p}<$ 0.05, Fig. 4f).

Total extractable PA pools changed significantly (1-way ANOVA, p < 0.001) with increasing initial concentrations of silicate, but the response was very different from that seen with $\mathrm{N}$ or $\mathrm{P}$ limitation (Fig. 4g). Total extractable PA increased from $36 \pm$ $1 \mathrm{amol} \mathrm{cell}^{-1}$ in Si-starved cultures to $42 \pm 3 \mathrm{amol}$ 
cell $^{-1}$ in cultures with $5 \mu \mathrm{mol} \mathrm{l}^{-1}$ initial silicate concentration, then declined to $19 \pm 1 \mathrm{amol} \mathrm{cell}^{-1}$ as the initial $\mathrm{SiO}_{3}$ concentration increased to $50 \mu \mathrm{mol} \mathrm{l} \mathrm{l}^{-1}$ (Fig. 4g). Extractable pools of PUT, SPD and NSPD all followed a similar trend to the total extractable PA pool and varied under different $\mathrm{SiO}_{3}$ concentrations (1-way ANOVA, p < 0.001; Fig. 4h). Again, NSPM was only detected in $\mathrm{Si}$-amended cultures and the concentration did not change with the amendment size $\left(\sim 1 \mathrm{amol} \mathrm{cell}^{-1}\right.$; 1 -way ANOVA, $\mathrm{p}=0.2$; Fig. $\left.4 \mathrm{~h}\right)$. Samples for analysis of PA in media of cultures grown with $5 \mu \mathrm{mol} \mathrm{l}{ }^{-1}$ added $\mathrm{SiO}_{3}$ were lost before they could be processed. NSPD was the only PA detected in the remaining samples and its extracellular concentration was similar $\left(\sim 7 \mathrm{nmol} \mathrm{l}^{-1}\right)$ in cultures with different initial $\mathrm{Si}$ concentrations (1-way ANOVA, $p>0.05$; Fig. 4i).

\section{Extractable PA pool vs. specific growth rate in T. pseudonana}

Our studies showed that the size of the extractable PA pool in T. pseudonana cells co-varied with specific growth rate $(\mu)$ (Fig. 5). When the growth of T. pseudonana was not limited by $\mathrm{Si}$, concentrations of total extractable PAs and of PUT, SPD and NSPD were all positively correlated with $\mu$ (Fig. $5 \mathrm{a}-\mathrm{d}_{i} \mathrm{p}<$ 0.05); however, the correlations were inverse when growth was limited by Si (Fig. $\left.5 \mathrm{e}-\mathrm{h}_{i} \mathrm{p}<0.05\right)$. The NSPM pool did not change as a function of $\mu(\mathrm{p}>0.5)$. The specific growth rates of $T$. pseudonana under limitations of $\mathrm{N}, \mathrm{P}$ and $\mathrm{Si}$ were determined from exponential growth before starting the semi-continuous culture.

\section{PUT uptake by $T$. pseudonana}

Our data demonstrate that T. pseudonana can take up PUT from the culture medium (Fig. 6). Cultures of T. pseudonana took up ${ }^{14} \mathrm{C}$ supplied as PUT from the medium at the fastest rate $\left(2.3 \pm 0.1 \mathrm{amol} \mathrm{cell}^{-1} \mathrm{~h}^{-1}\right.$; 1 -way ANOVA, $\mathrm{p}<0.0001$ ) under $\mathrm{S}=22$ and $\left[\mathrm{NO}_{3}{ }^{-}\right]=50 \mu \mathrm{mol} \mathrm{l} \mathrm{l}^{-1}$ (Table 2). We also found that T. pseudonana cells assimilated PUT at different rates when grown under different salinities and nitrate concentrations (2-way ANOVA, $\mathrm{p}<0.0001$; Fig. 6b, Table 2). PUT was taken up by T. pseudonana cells at a higher rate under lower salinity $(\mathrm{p}<$ $0.0001)$ or higher initial $\left[\mathrm{NO}_{3}{ }^{-}\right](\mathrm{p}<0.05$; Table 2$)$ and there was no significant interaction between salinity and nitrate concentration $(p>0.05)$.

\section{DISCUSSION}

\section{Extractable PA profiles in phytoplankton}

The composition of extractable PA pools differed greatly among the 4 phytoplankton species we tested, even though Thalassiosira pseudonana and Chaetoceros sp. are both centric diatoms, suggesting that PA composition profiles are species specific in phytoplankton. The frequent detection of PUT, SPD, NSPD and NSPM is similar to the results of previous studies of PA profiles in phytoplankton (Hamana \& Matsuzaki 1982, 1985, Nishibori \& Nishio 1997, Lu \& Hwang 2002, Nishibori \& Nishijima 2004). We found that the cyanobacterium Synechococcus sp. contained an extractable PA concentration that was comparable to that of diatoms (100s of $\mu \mathrm{mol} \mathrm{l}^{-1}$ of biovolume), despite the large difference in the size of these cells (Table 1). The dinoflagellate Amphidinium carterae contained the highest concentration of extractable PA (1000s of $\mu \mathrm{mol} \mathrm{l}^{-1}$ ) among the phytoplankton species that we studied, indicating the potential of dinoflagellates to contribute significantly to the dissolved PA pool of the ocean. The PAs we found in these species included most of the PAs commonly detected in the ocean (Nishibori et al. 2001a,b, 2003, Nishibori \& Nishijima 2004, Lu et al. 2014, Liu et al. 2015), suggesting that variability of PA concentrations in seawater could be a consequence of varying composition in phytoplankton communities.

\section{PA profiles during growth of $T$. pseudonana}

Our study showed that PA concentration and composition changed at different points during the growth of $T$. pseudonana; however, the steady increase in PA concentration we detected differed from the trend seen in other groups of phytoplankton (dinoflagellates, Chlorophyceae and Raphidophyceae), where PA concentrations were reported to decrease as cells lost viability (Kotzabasis \& Senger 1994, Lu \& Hwang 2002, Theiss et al. 2002, Nishibori \& Nishijima 2004, Nishibori et al. 2006). This difference might be attributed to the unique function of PAs in the synthesis of the nano-silicate structure of the diatom cell wall, and in the role of silicate in diatom cell division (Kröger et al. 2000, Sumper \& Lehmann 2006, Sumper \& Brunner 2008). The failure to detect extractable PUT and SPD in diatoms during the early stages of log phase growth could be due to the conjugation of PAs into silafins (proteins involved in silica precipitation) or into long-chain polyamines 

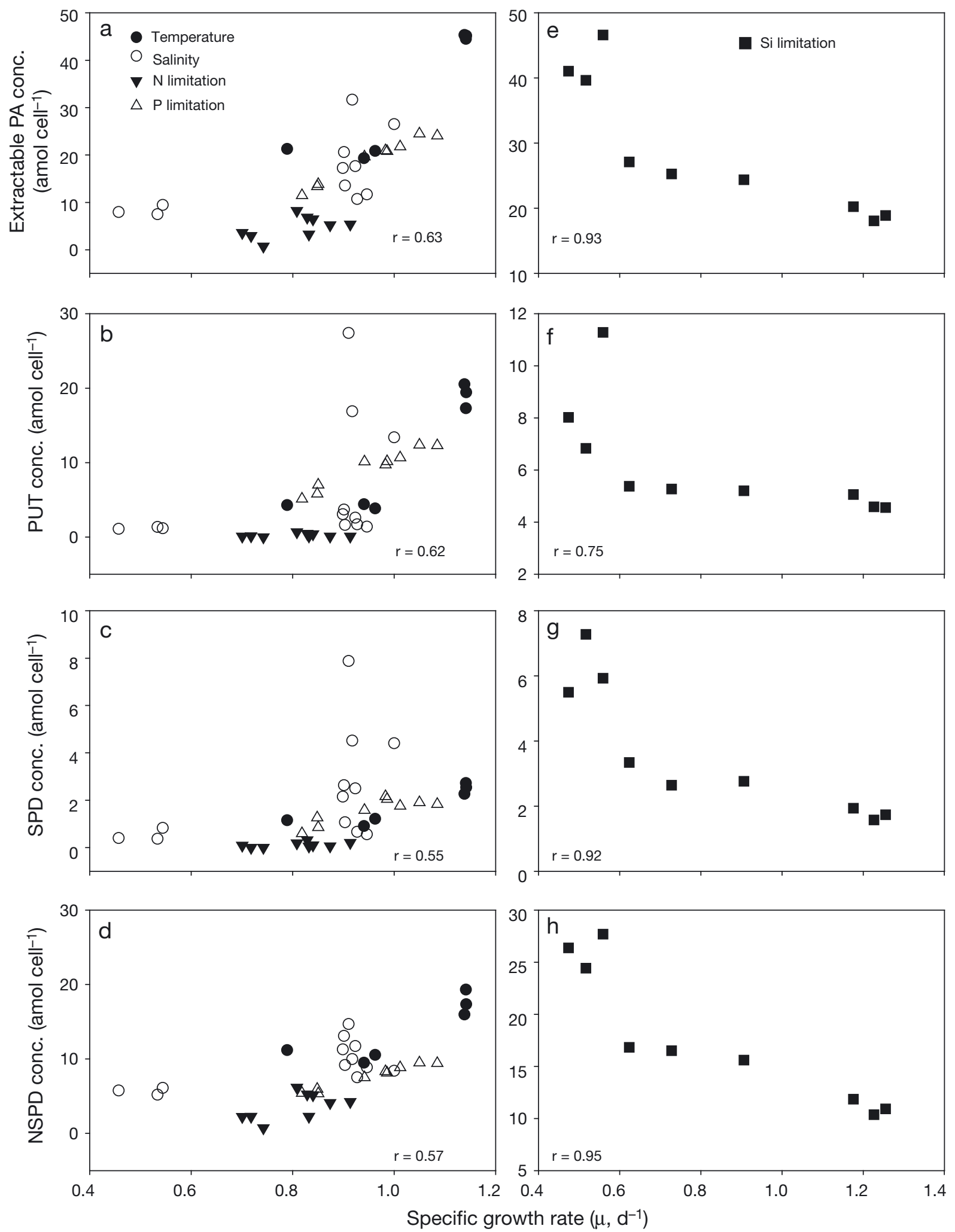

Fig. 5. Correlations between concentrations of (a) total extractable polyamines (PAs), (b) putrescine (PUT), (c) spermidine (SPD), and (d) norspermidine (NSPD) with specific growth rates $\left(\mu ; \mathrm{d}^{-1}\right)$ of Thalassiosira pseudonana under different growth conditions $(\mathrm{p}<0.05)$. Panels $(\mathrm{e}-\mathrm{h})$ show correlations between concentrations of total extractable PAs, PUT, SPD, and NSPD with $\mu$ of T. pseudonana grown under silicate limitation $(\mathrm{p}<0.05)$ 

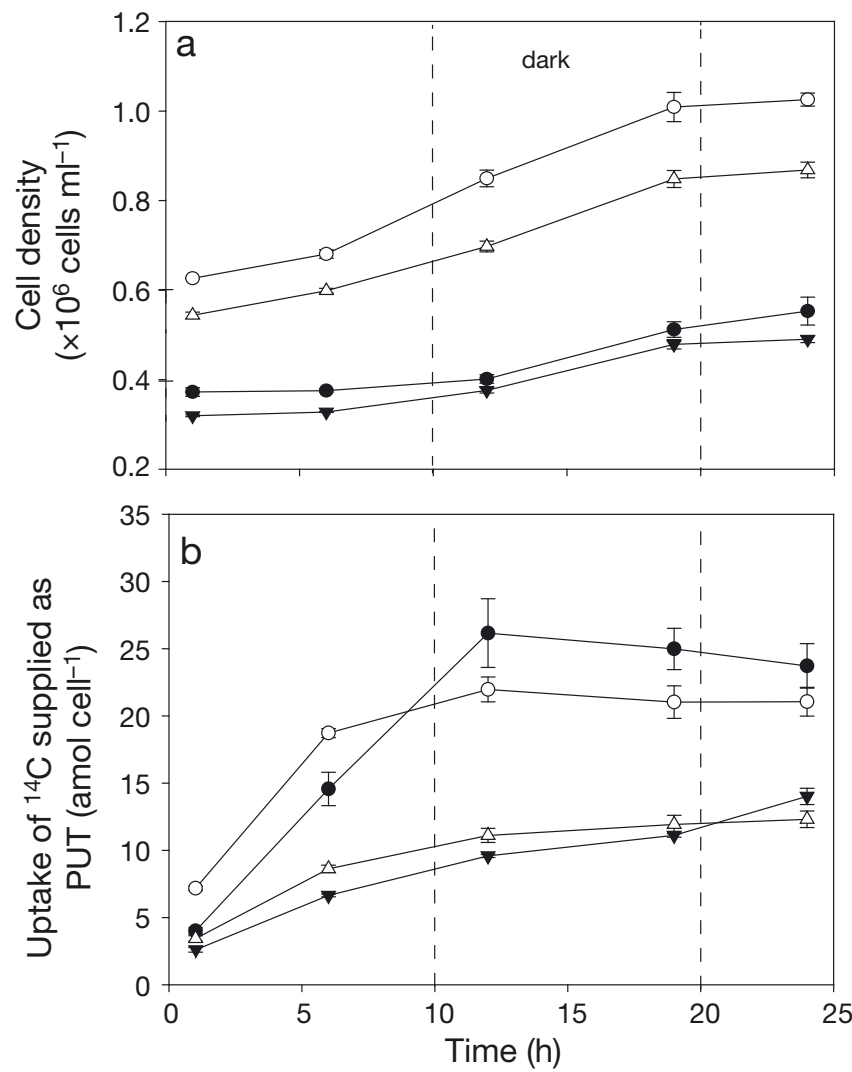

Fig. 6. Time courses of (a) Thalassiosira pseudonana abundance and (b) uptake of ${ }^{14} \mathrm{C}$ supplied as ${ }^{14} \mathrm{C}$-putrescine by $T$. pseudonana cells grown under different culture conditions (filled circles: $\mathrm{S}=22,\left[\mathrm{NO}_{3}{ }^{-}\right]=20 \mu \mathrm{mol} \mathrm{l}^{-1}$; open circles: $\mathrm{S}=$ $22,\left[\mathrm{NO}_{3}{ }^{-}\right]=50 \mu \mathrm{mol}{ }^{-1}$; filled triangles: $\mathrm{S}=32,\left[\mathrm{NO}_{3}{ }^{-}\right]=20$ umol ${ }^{-1}$; open triangles: $\mathrm{S}=32,\left[\mathrm{NO}_{3}^{-}\right]=50 \mu \mathrm{mol} \mathrm{l^{-1 }} ; \mathrm{S}=$ salinity. Light and dark periods are separated by vertical dashed lines. The concentration of ${ }^{14} \mathrm{C}$ from putrescine in the cell (amol cell ${ }^{-1}$ ) was calculated by dividing disintegrations per minute (DPM) taken up by cells by the specific activity of ${ }^{14} \mathrm{C}$ putrescine and the number of cells in the sample. Error bars: standard error of 3 replicates

(LCPAs) in the cell wall (Sumper et al. 2005, Bridoux \& Ingalls 2010). When cells began to die at the end of the stationary phase, PAs (especially PUT) may accumulate intracellularly as a result of low rates of silicate precipitation, or as a result of dissolution of the cell wall and catabolism of cell wall structures, including silafins and LCPAs.

\section{Effect of environmental factors on extractable PA pools of $T$. pseudonana}

Temperature and salinity are 2 important environmental factors in the microbial ecology of the coastal environment. Growth rates of phytoplankton are influenced by both of these factors (Eppley 1972,
Balzano et al. 2011). The strong correlation between extractable PA concentrations and growth rates of $T$. pseudonana suggests that PA pools in the cell are directly affected by growth (Fig. 5). Thus, temperature and salinity may control the intracellular PA pool indirectly by affecting the growth rate. Moreover, PA biosynthesis in T. pseudonana cells is assumed to use the ornithine decarboxylase-mediated pathway (Armbrust et al. 2004). Ornithine is also the precursor of proline, an osmolyte synthesized by the cell, and Liu \& Hellebust (1976) found that proline was synthesized in the diatom Cyclotella cryptica as salinity increased to $>30$. Thus, our observation that concentrations of extractable PAs in T. pseudonana decreased as salinity increased could be a consequence of suppressed PA synthesis via the ornithine decarboxylase-mediated pathway in favor of osmolyte production. The significant increase in the concentration of extractable PAs under heat stress could also be a consequence of a high demand for PA in order to stabilize DNA against heat denaturation (Balasundaram et al. 1996, Valdés-Santiago \& Ruiz-Herrera 2014).

Nutrient availability is known to influence the chemical composition of phytoplankton (Harrison et al. 1990, Johanssen \& Granéli 1999). Specifically, N or P limitation was found to reduce the cell quota of that element in phytoplankton (Johanssen \& Granéli 1999). Silica is important to the growth of diatoms because of its role in cell wall structure (Kröger et al. 2000, Sumper \& Kröger 2004, Bridoux \& Ingalls $2010)$. Since PAs have a high $N$ content $(\geq 2)$, it is perhaps not surprising that their intracellular concentrations vary with nitrogen availability (Altman \& Levin 1993, Minocha et al. 2000). PUT and SPD were not detected in N-starved cells of T. pseudonana, suggesting complete inhibition of PUT biosynthesis when $\mathrm{N}$ is not available. Phosphorus might not affect the PA content of phytoplankton as directly as nitrogen; however, P-limitation may affect phytoplankton $\mathrm{N}$ metabolism indirectly. Studies with higher plants have shown that $\mathrm{NO}_{3}$ uptake decreased by $70 \%$, and that uptake of $\mathrm{NO}_{3}$ and $\mathrm{NH}_{4}$ together decreased by $>80 \%$ under P limitation (Schjørring 1986, Rufty et al. 1990). The relatively large pool of PAs, especially PUT and SPD, found under P-limitation versus $\mathrm{N}$-limitation suggests that $\mathrm{N}$ availability controls the PA pool.

Gröger et al. (2008) used solid-state ${ }^{29} \mathrm{Si}$ NMR spectroscopy to suggest that the transport of Si into $T$. pseudonana was facilitated by rapid binding to PAs and the formation of partially polymerized silica, and that new girdle bands and valves were then formed during cell division. Thus, silicate supply can be ex- 
Table 2. Uptake rate of ${ }^{14} \mathrm{C}$ supplied as putrescine by Thalassiosira pseudonana cells. Rates of uptake were determined from triplicate $8 \mathrm{ml}$ samples taken 1 and $6 \mathrm{~h}$ after the addition of ${ }^{14} \mathrm{C}$-putrescine. Values are means $\pm \mathrm{SE}$

\begin{tabular}{|c|c|c|c|}
\hline \multirow[t]{2}{*}{ Treatment } & \multicolumn{3}{|c|}{$\begin{array}{c}\text { Uptake rate of }{ }^{14} \mathrm{C} \text { supplied as putrescine }- \\
\left(\text { amol cell }{ }^{-1} \mathrm{~h}^{-1}\right)\end{array}$} \\
\hline & {$\left[\mathrm{NO}_{3}{ }^{-}\right]=20 \mu \mathrm{mol} \mathrm{l} \mathrm{l}^{-1}$} & {$\left[\mathrm{NO}_{3}^{-}\right]=50 \mu \mathrm{mol} \mathrm{l} \mathrm{l}^{-1}$} & Mean of row \\
\hline Salinity $=22$ & $2.1 \pm 0.2$ & $2.3 \pm 0.1$ & $2.2 \pm 0.1$ \\
\hline Salinity = 32 & $0.8 \pm 0.02$ & $1.0 \pm 0.05$ & $0.9 \pm 0.1$ \\
\hline Mean of column & $1.5 \pm 0.3$ & $1.7 \pm 0.3$ & \\
\hline
\end{tabular}

the concentrations and composition of dissolved PAs detected in the environment.

The extracellular PA concentration responded differently from extractable pools in response to N- versus Silimitation. Extracellular PAs were most abundant in T. pseudonana cultures with lower $\mathrm{N}$ amendments compared to those in cultures with initial $\left[\mathrm{NO}_{3}\right]$ over the range tested $(\leq 50 \mu \mathrm{mol}$

pected to have an inverse effect on PA concentrations in the cell. The large pool of PAs observed under Si starvation suggests that Si limitation does not inhibit PA synthesis, but rather that subsequent removal of PA depends on the ongoing formation of cell wall components and is inhibited when growth and cell division cease. Higher initial silicate concentrations supported more growth and enhanced silicate precipitation with the accompanying production of LCPA and proteins. The coincidence of decreased PA content and increased silicate quota in diatoms is consistent with the need for PAs in forming the cell wall structure.

\section{Extracellular PAs from T. pseudonana}

Since PAs were not supplied in the original culture medium, PAs detected in the medium during growth of T. pseudonana must have been a result of PA released from cells. However, PAs dissolved in the medium were not present at the same concentration ratios as found in the intracellular pool, indicating selective release or uptake of PAs by phytoplankton. We found that T. pseudonana can take up PUT added to the medium (Fig. 6b), suggesting that the PA concentration measured in the medium may be the net of PA release minus uptake by $T$. pseudonana in these axenic cultures. Selective release of PA may provide another way that the composition of intracellular and extracellular PA pools could diverge. However, the correlation between extracellular and extractable PA concentrations under most of the conditions that we studied suggests passive permeation or diffusion of PAs through the cell membrane of $T$. pseudonana into the medium, similar to the fluxes of urea or amino acids (Bjørnsen 1988). The composition of extracellular PAs thus appears to be regulated by the composition and concentrations of intracellular PAs, differences in the permeability of the cell membrane to individual PAs and uptake by T. pseudonana. Uptake by bacterioplankton would further modify
$1^{-1}$ ). The relatively high concentration of PA in the medium of $\mathrm{N}$-deficient cultures could be driven by the release of PA from N-stressed cells when reacquisition of extracellular PAs was limited by a low growth rate. As $\mathrm{N}$-limitation declined, PA release may have been counteracted by uptake from the medium (Bjørnsen 1988). Silicate limitation has been shown to cause amino acid release by diatoms (Admiraal et al. 1984), possibly as a result of inhibition of cell division (Hammer \& Brockmann 1983). PAs were detected in media of Si-limited cultures, and their concentrations were large and similar between treatments (Fig. 4i). It is also noteworthy that the identity of the PA released to the medium differed with the limiting nutrient: SPD was released during N-limited growth while NSPD was released during P- or Si-limited growth (Fig. 4c,f,i). SPD is a minor component of the extractable pool of $T$. pseudonana during N-limited growth, whereas NSPD is a major component of the extractable pools under P- or Si-limited growth (Fig. 4b,e,h).

\section{Ecological significance}

The widespread occurrence of PAs in the ocean has been documented, and their distribution varies spatially and temporally. Based on the results presented here and from previous work, the distribution of PAs in the ocean can be assumed to be influenced by the abundance and composition of phytoplankton (Lee 1992, Lee \& Jørgensen 1995, Liu et al. 2015), since different phytoplankton species contain distinct PA profiles (Hamana \& Matsuzaki 1982, 1985, Nishibori et al. 2001a, 2003). However, we found that the release of PAs by phytoplankton appears to be selective, possibly as a result of net exchange between cells and the medium. Regardless of the mechanism, the relationship between internal and external PA pools is not straightforward and is controlled by environmental conditions as well as by phytoplankton community composition. Our studies of the diatom $T$. 
pseudonana showed that the concentrations of PA in the medium of healthy, exponentially growing cultures was very low $\left(<10 \mathrm{nmol} \mathrm{l}^{-1}\right)$ and was consistent with the concentrations found in seawater (Nishibori et al. 2001a,b, 2003, Liu et al. 2015). This suggests that the elevated PA concentrations reported in some studies (Lee 1992, Lee \& Jørgensen 1995) resulted from losses from unhealthy cells, or possibly as a consequence of damage and loss of cell membrane integrity due to grazing by zooplankton (Conover 1966, Dagg 1974) or viral lysis (Wilhelm \& Suttle 1999), with uptake by bacterioplankton (Lee 1992, Lee \& Jørgensen 1995, Liu et al. 2015) further complicating the dynamics of dissolved PA.

Acknowledgements. We thank Dr. Ming-Yi Sun for providing laboratory spaces for algal culture and Dr. Brian Hopkinson and Ms. Chen Shen for supplying artificial seawater medium ESAW and access to the Z2 Coulter ${ }^{\circledR}$ Particle Count and Size Analyzer. This paper is dedicated to Cindy Lee and Manfred Höfle, pioneers in environmental polyaminology. The research was funded by the National Science Foundation (NSF OCE 10-29742 to J.T.H.).

\section{LITERATURE CITED}

Admiraal W, Laane RWPM, Peletier H (1984) Participation of diatoms in the amino acid cycle of coastal waters; uptake and excretion in cultures. Mar Ecol Prog Ser 15:303-306

Alcázar R, Marco F, Cuevas J, Patron M and others (2006) Involvement of polyamines in plant response to abiotic stress. Biotechnol Lett 28:1867-1876

> Altman A, Levin N (1993) Interactions of polyamines and nitrogen nutrition in plants. Physiol Plant 89:653-658

> Armbrust EV, Berges JA, Bowler C, Green BR and others (2004) The genome of the diatom Thalassiosira pseudonana: ecology, evolution, and metabolism. Science 306 : 79-86

Bagga S, Dharma A, Phillips GC, Kuehn GD (1991) Evidence for the occurrence of polyamine oxidase in the dicotyledonous plant Medicago sativa L. (alfalfa). Plant Cell Rep 10:550-554

Balasundaram D, Tabor CW, Tabor H (1996) Sensitivity of polyamine-deficient Saccharomyces cerevisiae to elevated temperatures. J Bacteriol 178:2721-2724

Balzano S, Sarno D, Kooistra WHCF (2011) Effects of salinity on the growth rate and morphology of ten Skeletonema strains. J Plankton Res 33:937-945

Bjørnsen PK (1988) Phytoplankton exudation of organic matter: Why do healthy cells do it? Limnol Oceanogr 33: 151-154

Bouchereau A, Aziz A, Larher F, Martin-Tanguy J (1999) Polyamines and environmental challenges: recent development. Plant Sci 140:103-125

Bridoux MC, Ingalls AE (2010) Structural identification of long-chain polyamines associated with diatom biosilica in a Southern Ocean sediment core. Geochim Cosmochim Acta 74:4044-4057

Conover RJ (1966) Feeding on large particles by Calanus hyperboreus. In: Barnes H (ed) Some contemporary studies in marine science. George Allen and Unwin, London, p 187-194

$>$ Dagg MJ (1974) Loss of prey body contents during feeding by an aquatic predator. Ecology 55:903-906

Eppley WR (1972) Temperature and phytoplankton growth in the sea. Fish Bull 70:1063-1085

Fuell C, Elliott AK, Hanfrey CC, Franceschetti M, Michael AJ (2010) Polyamine biosynthesis diversity in plants and algae. Plant Physiol Biochem 48:513-520

> Galston AW, Sawhney RK (1990) Polyamines in plant physiology. Plant Physiol 94:406-410

- Gröger C, Sumper M, Brunner E (2008) Silicon uptake and metabolism of the marine diatom Thalassiosira pseudonana: solid-state 29Si NMR and fluorescence microscopic studies. J Struct Biol 161:55-63

Hamana K, Matsuzaki S (1982) Widespread occurrence of norspermidine and norspermine in eukaryotic algae. $\mathrm{J}$ Biochem 91:1321-1328

> Hamana K, Matsuzaki S (1985) Further study on polyamines in primitive unicellular eukaryotic algae. J Biochem 97: 1311-1315

- Hamana K, Matsuzaki S (1992) Polyamines as a chemotaxonomic marker in bacterial systematics. Crit Rev Microbiol 18:261-283

> Hammer KD, Brockmann UH (1983) Rhythmic release of dissolved free amino acids from partly synchronized Thalassiosira rotula under nearly natural conditions. Mar Biol 74:305-312

Harrison PJ, Waters RE, Taylor FJR (1980) A broad spectrum artificial medium for coastal and open ocean phytoplankton. J Phycol 51:255-263

Harrison PJ, Thompson PA, Calderwood GS (1990) Effects of nutrient and light limitation on the biochemical composition of phytoplankton. J Appl Phycol 2:45-56

Haxo FT, Kycia JH, Somers GF, Bennett A, Siegelman HW (1976) Peridinin-chlorophyll a proteins of the dinoflagellate Amphidinium carterae (Plymouth 450). Plant Physiol 57:297-303

Incharoensakdi A, Jantaro S, Raksajit W, Mäenpää P (2010) Polyamines in cyanobacteria: biosynthesis, transport and abiotic stress response. In: Méndez-Vilas A (ed) Current research, technology and education topics in applied microbiology and microbial biotechnology. Formatex Research Center, Badajoz, p 23-32

Johansson N, Granéli E (1999) Influence of different nutrient conditions on cell density, chemical composition and toxicity of Prymnesium parvum (Haptophyta) in semi-continuous cultures. J Exp Mar Biol Ecol 239:243-258

Kilham SS (1978) Nutrient kinetics of freshwater planktonic algae using batch and semicontinuous methods. Mitt Int Ver Theor Angew Limnol 21:147-157

Kotzabasis K, Senger H (1994) Free, conjugated and bound polyamines during the cell cycle in synchronized cultures of Scenedesmus obliquus. Z Natforsch C Biosci 49: 181-185

- Kröger N, Deutzmann R, Bergsdorf C, Sumper M (2000) Species-specific polyamines from diatoms control silica morphology. Proc Natl Acad Sci USA 97:14133-14138

Kusano T, Yamaguchi K, Berberich T, Takahashi Y (2007) Advances in polyamine research in 2007. J Plant Res 120: 345-350

Lee C (1992) Controls on organic carbon preservation: the use of stratified water bodies to compare intrinsic rates of decomposition in oxic and anoxic systems. Geochim Cosmochim Acta 56:3323-3335 
Lee C, Jørgensen NOG (1995) Seasonal cycling of putrescine and amino acids in relation to biological production in a stratified coastal salt pond. Biogeochemistry 29: 131-157

Lee J, Sperandio V, Frantz DE, Longgood J, Camilli A, Phillips MA, Michael AJ (2009) Genomics, proteomics, and bioinformatics: an alternative polyamine biosynthetic pathway is widespread in bacteria and essential for biofilm formation in Vibrio cholerae. J Biol Chem 284: 9899-9907

Liu MS, Hellebust JA (1976) Effects of salinity and osmolarity of the medium on amino acid metabolism in Cyclotella cryptica. Can J Bot 54:938-948

Liu Q, Lu X, Tolar BB, Mou X, Hollibaugh JT (2015) Concentrations, turnover rates and fluxes of polyamines in coastal waters of the South Atlantic Bight. Biogeochemistry 123:117-133

Lu YH, Hwang DF (2002) Polyamine profile in the paralytic shellfish poison-producing alga Alexandrium minutum. J Plankton Res 24:275-279

Lu XX, Zou L, Clevinger C, Liu Q, Hollibaugh JT, Mou XZ (2014) Temporal dynamics and depth variations of dissolved free amino acids and polyamines in coastal seawater determined by high-performance liquid chromatography. Mar Chem 163:36-44

Minocha R, Long S, Magill AH, Aber J, McDowell WH (2000) Foliar free polyamine and inorganic ion content in relation to soil and soil solution chemistry in two fertilized forest stands at the Harvard Forest, Massachusetts. Plant Soil 222:119-137

Nishibori N, Nishijima T (2004) Changes in polyamine levels during growth of a red-tide causing phytoplankton Chattonella antiqua (Raphidophyceae). Eur J Phycol 39:51-55

Nishibori N, Nishio S (1997) Occurrence of polyamines in the broom forming toxic dinoflagellate Alexandrium tamarense. Fish Sci 63:319-320

Nishibori N, Yuasa A, Sakai M, Fujihara S, Nishio S (2001a) Free polyamine concentrations in coastal seawater during phytoplankton bloom. Fish Sci 67:79-83

Nishibori N, Nishii A, Takayama H (2001b) Detection of free polyamine in coastal seawater using ion exchange chromatography. ICES J Mar Sci 58:1201-1207

- Nishibori N, Matuyama Y, Uchida T, Moriyama T, Ogita Y, Oda M, Hirota H (2003) Spatial and temporal variations in free polyamine distributions in Uranouchi Inlet, Japan. Mar Chem 82:307-314

Editorial responsibility: Steven Lohrenz,

New Bedford, Massachusetts, USA
Nishibori N, Fujihara S, Nishijima T (2006) Changes in intracellular polyamine concentration during growth of Heterosigma akashiwo (Raphidophyceae). Fish Sci 72: 350-355

> Orsini F, Accorsi M, Gianquinto G, Dinelli G and others (2011) Beyond the ionic and osmotic response to salinity in Chenopodium quinoa: functional elements of successful halophytism. Funct Plant Biol 38:818-831

> Porter KG, Feig YS (1980) The use of DAPI for identifying and counting aquatic microflora. Limnol Oceanogr 25: 943-948

Rodriguez-Garay B, Phillips GC, Kuehn GD (1989) Detection of norspermidine and norspermine in Medicago sativa L. (alfalfa). Plant Physiol 89:525-529

Rufty TW, Mackown CT, Israel DW (1990) Phosphorus stress effects on assimilation of nitrate. Plant Physiol 94: 328-333

Schjørring JK (1986) Nitrate and ammonium absorption by plants growing at a sufficient or insufficient level of phosphorus in nutrient solutions. Plant Soil 91:313-318

Stevens L (1970) The biochemical role of naturally occurring polyamines in nucleic acid synthesis. Biol Rev Camb Philos Soc 45:1-27

Sumper M, Brunner E (2008) Silica biomineralisation in diatoms: the model organism Thalassiosira pseudonana. ChemBioChem 9:1187-1194

Sumper M, Kröger N (2004) Silica formation in diatoms: the function of long-chain polyamines and silaffins. J Mater Chem 14:2059-2065

Sumper M, Lehmann G (2006) Silica pattern formation in diatoms: species-specific polyamine biosynthesis. ChemBioChem 7:1419-1427

> Sumper M, Brunner E, Lehmann G (2005) Biomineralization in diatoms: characterization of novel polyamines associated with silica. FEBS Lett 579:3765-3769

Tabor CW, Tabor H (1985) Polyamines in microorganisms. Microbiol Rev 49:81-99

> Theiss C, Bohley P, Voigt J (2002) Regulation by polyamines of ornithine decarboxylase activity and cell division in the unicellular green alga Chlamydomonas reinhardtii. Plant Physiol 128:1470-1479

> Valdés-Santiago L, Ruiz-Herrera J (2014) Stress and polyamine metabolism in fungi. Front Chem 1:art42, doi:10.3389/fchem.2013.00042

> Wilhelm SW, Suttle CA (1999) Viruses and nutrient cycles in the sea. Bioscience 49:781-788

Submitted: August 28, 2015; Accepted: December 14, 2015 Proofs received from author(s): February 13, 2016 